$$
\text { قسمـ : أمراض الدواجسـنـ }
$$

كلية الطب البيطري - جامعة أسيوطن

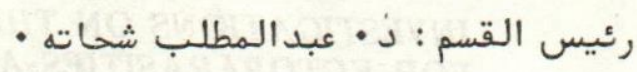

$$
\begin{aligned}
& \text { دراسات فاعلية الايفرمكتين في علاج } \\
& \text { الطفيليات الخارجية والديدان الاسطوانية في الدجاج } \\
& \text { rـ تأثير الايفرمكتين عن عن طريق الفم }
\end{aligned}
$$

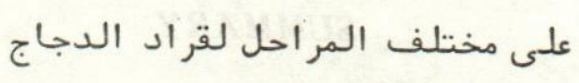

هلاح موسى ، اهد جاد ، عادل سليمان ، ابر اهيم سكر ، محمود عبدالرحيم

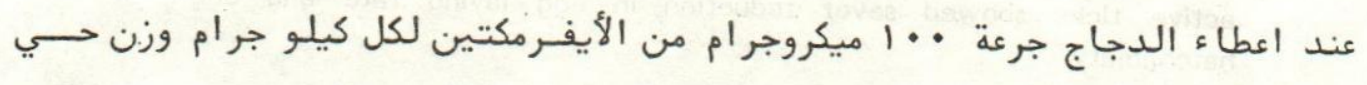

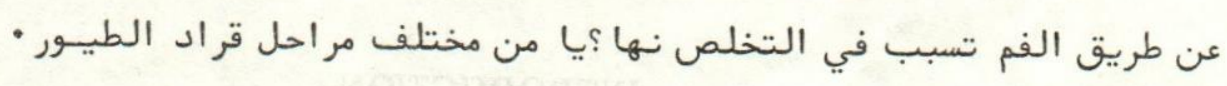

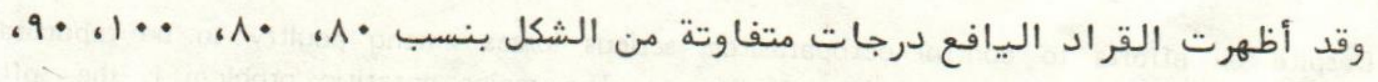

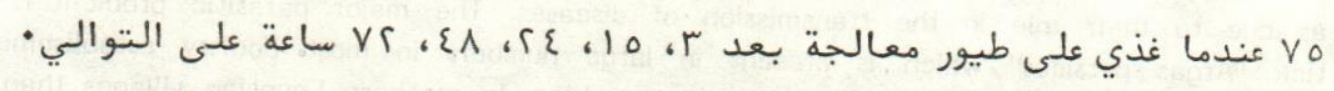$$
\text { وكذلك أظهر القراد الذي لم يتأثر ظاهرا انخفاض في معدل وضع البيض ونســـب }
$$

الفقـس 
Dept. of Poultry Diseases,

Faculty of Vet. Med., Assiut University,

Head of Dept. Dr. M.A. Shehata.

\title{
INVESTIGATIONS ON THE EFFICACY OF IVERMECTINE FOR ECTOPARASITIES AND NEMATODES IN CHICKENS \\ III. EFFECT OF ORAL ADMINISTRATION OF IVERMECTINE \\ ON DIFFERENT STAGES OF "ARGAS PERSICUS"
}

(With 2 Tables)

\author{
By \\ S. MOUSA; NAHED GAD; A. SOLIMAN; I. SOKKAR \\ and M. ABDEL-RAHEEM * \\ (Received at 13/10/1987)
}

\section{SUMMARY}

An oral dose of $100 \mathrm{ug}$ Ivermectine per $\mathrm{kgm}$ bodyweight proved to be the suitable theraputic dose which resulted in complete erradication of different stages of fowl ticks.

Engorged ticks showed 80, 80, 100, 90 and $75 \%$ paralysis when fed on treated birds after 3, 15, 24, 48 and 72 hours respectivelly, active ticks showed sever reduction in egg laying rate and egg hatchability.

\section{INTRODUCTION}

Despite all efforts to control ectoparasites, serious losses among poultry to be reported as due to their role in the transmission of diseases. The major parasitic problem is the soft tick "Argas persicus" which is present in large numbers in most poultry establishments. Due to climatic differences, it is a more serious problem in southern Egyptian villages than in those in Delta (REID, 1956).

Many drugs have been used to control the parasite both on the host and premises, but laborious individual bird application methods are inappropriate to modern poultry production (SEN, 1938 and GAD, 1982).

The acaricidal effect of lvermectine after oral or subcutaneous administration to cattle and sheep have been documented in many publications (DRUMMEND, et al. 1981 and PERGRAM \& LEMCHE, 1985).

The purpose of the present work was to study the effect of different doses of lvermectine given orally to chickens on different stages of "Argas persicus" at various time intervals post-treatment.

* Dept. of Pharmacology, Fac. of Medicine, Assiut Univ. 


\section{S. MOUSA, et al.}

\section{MATERIAL and METHODS}

\section{Fowl Tick Colonies:}

All collected stages were identified according to the criteria given by LOUNSBURY, 1903; HOOGSTRALL, 1956; SONENSHINE, et al. 1962; SOLIMAN, 1965 and GAD, 1982.

\section{Laboratory Rearing of Argas Persicus:}

Larvae, nymphs and adult stages were fed on white leghorn chickens according to the procedure described by MICKS, 1951 and GAD, 1982.

Moulting process and mating of fowl ticks occured 24 hours after engorgment of both sexes and then incubated individually. Three weeks after egg deposition, hatched larvae attached themselves to the host. After full engorgment larvae dropped off within 3-5 days especially at night looking a hiding place (BISHOPP, 1919 and HOOGSTRALL, 1956).

\section{Drug:}

Ivermectine (Otherwise known as M.K. 933 or 22,23 dihydro-avermectine B1: Merck Sharp \& Dohme) was supplied in a formulation containing the drug in $1 \%$ concentration.

\section{Experimental Design:}

Experment l:

Efficacy of drug on engorged ticks fed on donor treated birds with $100 \mathrm{Ug} / \mathrm{kgm} . \mathrm{B} . \mathrm{W}$. of Ivermectine after different time intervals.

\section{Experiment It:}

Effect of different doses of Ivermectine was studied. Doses of 50, 100 and $150 \mathrm{ug} / \mathrm{kgm}$. B.W. were given orally to donor birds. Nymph and adult ticks were fed on these birds 24 hours post-treatment (P.T.). Engorged ticks were observed daily.

\section{Experiment Ill:}

Effect of the drug on larval stages was studied. Groups of 150-200 highly active hatched larvae were fed at 24 hours P.T. by $100 \mathrm{ug} / \mathrm{kgm} . \mathrm{B} . W$. Ivermectine. Results were recorded after 3 trials.

Control groups of ticks were fed on non treated donor chickens parallel to all experimental groups.

\section{RESULTS}

\section{Experiment l:}

The effect of a single dose of Ivermectine on ticks fed after different time intervals are shown in table (1).

Percentage of paralysed ticks were 80, 80, 100, 90 and $75 \%$ after 3, 15, 24, 48 and 72 hours P.T. respectively.

Results of egg-laying: observation of treated stages revealed no evidence of excretion even in active ticks. The ability of egg laying was markedly reduced and the hatchability rate varied from $20-5 \%$ as shown in table (2). 


\section{EFFECT OF EVERMECTINE}

\section{Experiment II:}

Effect of different doses of Ivermectine 50, 100 and $150 \mathrm{ug} / \mathrm{kgm} . \mathrm{B} . W$. on Argas persicus. at 24 hours P.T.

In 1st. group 20\% paralysis percent, in 2nd. group 100\%, on 3rd group $100 \%$ and in control group $0 \%$. From these results, it is clear that the effect of $100 \mathrm{ug} / \mathrm{kgm} . \mathrm{B} . W$. is the suitable theraputic dose.

\section{Experiment III:}

By observation, the red inflamatory biting ateas allover the body of donor chickens were detected, but larvae were not noticed.

On the other hand attached seed ticks (engorged' larave) were easily observed 3-5 days post-feeding, engorged larvae dropped off and were collected in the control group.

Table (1)

The efficacy of $100 \mathrm{ug} / \mathrm{kgm}$ B.W. Ivermectine on different stages of Argas persicus

\begin{tabular}{|c|c|c|c|c|c|c|c|c|c|c|c|c|c|c|c|c|c|c|}
\hline \multirow{2}{*}{$\begin{array}{l}\text { Groups } \\
\text { Stage }\end{array}$} & \multicolumn{3}{|c|}{$\begin{array}{l}\text { G I } \\
3 \text { h.pt }\end{array}$} & \multicolumn{3}{|c|}{$\begin{array}{c}\text { G II } \\
15 \text { h.pt }\end{array}$} & \multicolumn{3}{|c|}{$\begin{array}{c}\text { G III } \\
24 \text { h.pt }\end{array}$} & \multicolumn{3}{|c|}{$\begin{array}{c}\text { G IV } \\
48 \text { h.pt }\end{array}$} & \multicolumn{3}{|c|}{$\begin{array}{c}\text { G V } \\
72 \text { h.pt }\end{array}$} & \multicolumn{3}{|c|}{$\begin{array}{c}\text { Control } \\
\text { untreated }\end{array}$} \\
\hline & T. & A. & P. & T. & A. & P. & T. & A. & P. & T. & A. & P. & T. & A. & P. & T. & A. & P. \\
\hline Nymph & 20 & 3 & 17 & 20 & 4 & 16 & 20 & - & 20 & 20 & - & 20 & 20 & 2 & 18 & 20 & 20 & 0 \\
\hline Females & 20 & 4 & 16 & 20 & - & 20 & 20 & - & 20 & 20 & 4 & 16 & 20 & 8 & 12 & 20 & 20 & 0 \\
\hline Males & 20 & 5 & 15 & 20 & 8 & 12 & 20 & - & 20 & 20 & 2 & 18 & 20 & 5 & 15 & 20 & 20 & 0 \\
\hline Total & 60 & 12 & 48 & 60 & 12 & 48 & 60 & - & 60 & 60. & 6 & 54 & 60 & 15 & 45 & 60 & 60 & 0 \\
\hline Paralysis\% & & $80 \%$ & & & $80 \%$ & & & $100 \%$ & & & $90 \%$ & & & $75 \%$ & & & $0 \%$ & \\
\hline
\end{tabular}

T. : Total number of A.P. A. : number of active Argas. P. : number of paralysed Argas.

Table (2)

Effect of Ivermectine on fertilization (treated females and treated males)

\begin{tabular}{lcccc}
\hline Treated Females & 3 h.pt & 48 h.pt & 72 h.pt & Control \\
\hline No. of active females & 5 & 2 & 8 & 20 \\
Ovipostive females & 2 & 2 & 4 & 20 \\
The day of laying P.F. & 19 & 13 & 15 & 5 \\
No. of eggs/female & 45 & 40 & 17 & 95 \\
Hatching \% & $20 \%$ & $10 \%$ & $5 \%$ & $95 \%$ \\
\hline
\end{tabular}

P.F. : Post Fertilization. 


\section{S. MOUSA, et al.}

\section{DISCUSSION}

Many acaricides have been used to control tick infestation in poultry farms. However such treatments rely on indevidual bird application and premices, which is difficult to acheive in large poultry populations (SEN, 1938 and GAD, 1982).

Results of experiment I showed that the percentage of paralysed ticks were 80,80 , 100, 90 and $75 \%$ after 3, 15, 24, 48 and 72 hours P.T. respectivelly. Not only tick paralysis was observed but also egg laying and hatchability rate of active ticks was markedly reduced.

It could be concluded that the parameter of iyermectine reached its peak within 24 hours P.T. At this fixed time, different doses of ivermectine were tested in exp. II which revealed that a dose of $100 \mathrm{ug} / \mathrm{kg}$. B.W. was the suitable theraputic economic and safe dose in agreement to MOUSA, et al. (1986).

Exp. III showed that a dose of $100 \mathrm{ug} / \mathrm{kg} \cdot \mathrm{B} . \mathrm{W}$. resulted in $100 \%$ mortalities of tick larvae fed on treated birds. Larvae failed to held themselves attached on treated birds. The acaricidal effect of ivermectine have been documented by DRUMMOND, et al. (1981) and (PERGRAM \& LEMCHE, 1983).

It could be concluded that an oral dose of $100 \mathrm{ug} / \mathrm{kgm}$. B.W. when repeated after 2-3 weeks will be helpful for eradication of tick infestation regarding different stages of the parasite.

\section{REFERENCES}

Bishopp., F.C. (1919): The fowl tick and how premises may be freed from it. U.S.D.A. Farmers Bull 1070 cited from Gad (1982).

Drummond, R.O.; Wheststons, T.M.; Miller, D.A. (1981): Control of ticks systemically with Merck Mk- 933, an avermectin. Journal of Economic Entomology 74 (4) 432-436.

Gad, N. (1982): Studies on some blood protozoa and ectoparasites of birds with special reference to method of control D.V.Sc. thesis, Assiut Univ.

Hoogstraal, H. (1956): African Ixodoidea. Ticks of the Sudan. U.S. Naval. Medical Research unit. No. 3, Cairo, Egypt.

Lounsbury, G.P. (1903): The fowl tick studies on its life cycle and habits. Agric. D.C.G.H, 23 (3): $261-273$.

Micks, D.W. (1951): The laboratory rearing of the common fowl tick, Argas persicus (oken). J. parasit. 37 (1): 102-105.

Mousa, S.; N. Gad; I. Sokkar and M. Abd El Raheem (1986): Investigation the efficacy of ivermectine for ectoparasites and nematodes in chickens. 1- Testing for drug safty to chickens. Assiut Vet. Med. J. Vol. 17, 33: 225-228.

Pergram, R.G. d lemche (1985): Observations on the efficacy of Ivermectin in the control of cattle ticks in Zambia Vet. Record. 117, (21): 551-554.

Sen, P. (1938): A check and host of ixodoidea (Ticks) occurring in Indian. J. Vet. Sci., 8 (2): 133-147.

Soliman, M.R. (1965): Studies on certain ectoparasites of poultry. M.Sc. thesis, Ein Shams Univ., Cairo.

Sonenshine, D.E. and Clifford, C.M. and Kohls, G.M. (1962): The identification of larvae of the genus. Argas (Acarina, Argasidae). Acarologia 4 (2): 192-214. 
